Abstract-The movements of cultured $(n=18)$ and wild $(n=28)$ juvenile crimson jobfish (Pristipomoides filamentosus) are reported for a known nursery off windward Oahu, Hawaii. The 2 batches of fish were tagged with acoustic transmitters in separate years $(2006,2007)$ and monitored with a receiver array for up to 10 weeks. Of the cultured fish, $75 \%$ left the nursery within 3 days, more than twice the exit rate for wild fish tagged the following year. The number of wild fish detected peaked during daylight hours, indicating that the fish were diurnally active. Tidally driven changes in bottom temperature did not explain the behavioral patterns of the wild fish that remained in the nursery for multiple weeks. Additional receivers deployed on the slope adjacent to the nursery detected that twothirds of the wild fish departed from the nursery after a short period (mean: 1.2 days [SD 1.69]), by crossing areas with soft substrate similar to that of the nursery. In contrast, the fish that exited by rock ledges stayed near the rock ledges longer (mean: 13.3 days [SD 20.9]). These movement patterns provide insight into the early life history of this deepwater snapper and a glimpse at some of the challenges for future stock enhancement efforts.

Manuscript submitted 18 December 2013. Manuscript accepted 13 March 2015.

Fish. Bull. 113:231-241 (2015).

doi: 10.7755/FB.113.3.1

Online publication date: 7 April 2015.

The views and opinions expressed or implied in this article are those of the author (or authors) and do not necessarily reflect the position of the National Marine Fisheries Service, NOAA.

\title{
Acoustic tagging and monitoring of cultured and wild juvenile crimson jobfish (Pristipomoides filamentosus) in a nursery habitat
}

\author{
Frank A. Parrish (contact author) ${ }^{1}$ \\ Nicholas T. Hayman ${ }^{1}$ \\ Christopher Kelley² \\ Raymond C. Boland1 \\ Email address for contact author: frank.parrish@noaa.gov \\ 1 Pacific Islands Fisheries Science Center \\ NOAA Daniel K. Inouye Regional Center \\ 1845 Wasp Boulevard, Building 176 \\ Honolulu, Hawaii 96818 \\ 2 School of Ocean and Earth Science and Technology \\ University of Hawaii at Manoa \\ 1000 Pope Road \\ Honolulu, Hawaii 96822
}

Eteline snappers compose an important, high-value component of tropical insular fisheries throughout the Pacific and Indian Oceans, and catch of sizeable portions is exported from their country or archipelago of origin. The crimson jobfish (Pristipomoides filamentosus), also known as the pink snapper, composes more than a quarter of the commercial landings by weight of the Hawaiian bottomfish fishery (Brodziak et al., 2011). In addition, this species is thought to account for roughly the same percentage of bottomfish recreational landings, which, when added to commercial landings, would increase the overall catch of this snapper by a factor of 2-3 (Zeller et al., 2008). Because of the high market value of crimson jobfish, scientists of the University of Hawaii spent a considerable effort during 1997-2006 attempting to breed this species in captivity for potential use in aquaculture and stock enhancement. They were successful at maintaining broodstock, producing larvae, and rearing fish to 20-24 cm in fork length (FL) (C. Kelley, unpubl. data), which is similar to the size of juveniles that occur in nearshore nursery habitats.

Culturing large numbers of juveniles is not yet possible, but if it is achieved, they hypothetically could be grown for harvest in oceanic cages or used to enhance wild populations through releases to known nursery grounds as is done with other fisheries species (Bell et al., 2008). Although these types of enhancement activities have been undertaken for freshwater and anadromous species, their use in marine systems is more recent. Notable examples in Hawaii include hatchery releases of striped mullet (Mugil cephalus) (Leber and Arce, 1996) and Pacific threadfin (Polydactylus sexfilis) (Friedlander and Ziemann, 2003).

In order to release cultured fish into the wild for the purposes of stock enhancement, researchers will need to know where to deploy the fish and how they will behave. Ideally, cultured juvenile fish would be released in a place suitable for that stage of its life history. Larvae of eteline lutjanid snappers are known to reside in the plankton until they 
reach a length of 5-6 cm FL (Leis, 1987; Leis and Lee, 1994). Crimson jobfish settle and form loose schools over featureless soft-bottom habitat at depths of 80 $100 \mathrm{~m}$ (Parrish, 1989). While in their nursery they feed on benthic and, to a lesser extent, a mix of planktonic invertebrates and small nektonic fishes (DeMartini et al., 1996; Schumacher, 2011). Survey results indicate that slope areas close to sources of coastal discharge (e.g., draining embayments or reef channels) tend to support greater numbers of juveniles and serve as premium habitat or nursery grounds (Parrish et al., 1997). These nurseries are important gateways in the life history of the crimson jobfish and provide a window to understanding and predicting year-class fluctuations.

The most studied nursery ground for crimson jobfish in Hawaii is the offshore area of Kaneohe Bay, Oahu. Monthly sampling of the juvenile population in this area has revealed seasonal patterns in the distribution of fish sizes consistent with an annual progression of a year class through its recruitment, growth, and emigration to adult habitats (Moffitt and Parrish, 1996). Fish at sizes of $7-10 \mathrm{~cm}$ FL appear in this nursery habitat in the fall and stay there for a period of 6-7 months until they reach 20-30 cm FL (Moffitt and Parrish, 1996). Otolith features of juvenile crimson jobfish indicate ages of $\sim 6$ months for 10.5-cm-FL fish, about a year for 18.5-cm-FL fish, and 2 and 3 years, respectively, for 28.0- and 36.0-cm-FL fish (DeMartini et al., 1994; Andrews et al., 2012). At 2-3 years of age, fish begin to emigrate offshore to deeper habitats used by subadults (Okamoto ${ }^{1}$ ) and adults (Haight et al., 1993a). Because only 2 wild juvenile crimson jobfish had been tagged and tracked in the Kaneohe nursery (Moffitt and Parrish, 1996) before our study, there has been insufficient understanding of juvenile crimson jobfish movements and how they might compare with those of crimson jobfish raised in captivity.

In this study, we report new observations of 2 batches of juvenile crimson jobfish that were implanted with acoustic tags and released in separate years to the nursery habitat off windward Oahu. In the first year (2006) of this study, a batch of cultured fish were tagged and released, followed by a second year (2007) in which wild fish were collected from the nursery, tagged, held for observation, and then released. We investigated the hypotheses that cultured juvenile fish released to a known nursery site would linger and make use of the nursery habitat or move directly off to other locations. Similarly, we investigated whether the wild fish taken from the site, tagged, and released back to the nursery would behave differently from the cultured fish.

\footnotetext{
${ }^{1}$ Okamoto, H. Y. 1993. Project to develop opakapaka (pink snapper) tagging technique to assess movement behavior. Final Report of the Hawaii Department of Land and Natural Resources to NOAA, 18 p. NOAA Award No. NA90AAD-IJ466. [Available from Division of Aquatic Resources, Hawaii Department of Land and Natural Resources, 1151 Punchbowl Street, Room 330, Honolulu, HI 96813-3088.]
}

\section{Materials and methods}

\section{Study area}

The Kaneohe Bay nursery (Fig. 1) is a submerged terrace, $70-100 \mathrm{~m}$ deep, roughly $8 \mathrm{~km} 2$ in area, and is separated from the nearest known aggregation of adult crimson jobfish by more than $5 \mathrm{~km}$. Video surveys (Parrish et al., 1997), backscatter data collected with a multibeam sonar (Dartnell and Gardner ${ }^{2}$ ), and sidescan sonar data (C. Kelley, unpubl. data) indicate that the bottom at this nursery site is "soft" (unconsolidated sediment) and generally featureless. Two isolated, exposed rock ledges identified on the slope adjacent to the nursery were hypothesized to be potential transition habitats for juveniles when they leave the nursery to emigrate to deeper, hardbottom adult habitat.

\section{Receivers}

We monitored the nursery ground with two VR2 ${ }^{3}$ passive underwater receivers (VEMCO, Bedford, Canada), deployed in 2006 approximately $800 \mathrm{~m}$ apart at a depth of 75-80 m. Subsurface floats suspended the receivers $5 \mathrm{~m}$ above the bottom to maximize reception of signals from tagged fish. This configuration reduced acoustic effects on signal reception from the thermocline (Siderius et al., 2007). Weighted with a concrete anchor, the receivers were fitted with an ORE Offshore SWR acoustic release transponder (EdgeTech, West Wareham, MA) that detached and allowed the receivers to float to the surface when a coded acoustic signal was transmitted. In 2007, 4 additional receivers were deployed at a depth of $140 \mathrm{~m}$ at sites on the adjacent slope (2 north and 2 south of the nursery), and each pair was split between soft bottom (sites 2 and 4) and rock ledge (sites 1 and 3 ) habitats (Fig. 1). The receivers on the slope were separated from other receivers by distances ranging from 1200 to $2500 \mathrm{~m}$. Attached to the bottom of each receiver mooring, a temperature data logger recorded temperatures on an hourly basis to track tidal effects of a cold bottom layer that had been identified at the Kaneohe nursery in previous studies (Moffitt and Parrish, 1996).

\section{Tagging of juvenile fish}

Cultured juveniles were raised in captivity from eggs spawned from broodstock held at the Hawaii Institute of Marine Biology (HIMB), a marine research center of the University of Hawaii at Manoa located on Co-

\footnotetext{
2 Dartnell, P., and J. V. Gardner. 1999. Sea-floor images and data from multibeam surveys in San Francisco Bay, Southern California, Hawaii, the Gulf of Mexico, and Lake Tahoe, California-Nevada. U.S. Geological Survey Digital Data Series DDS-55, vers. 1.0. [Online version of interactive CDROM. Available at Website.]

${ }^{3}$ Mention of trade names or commercial companies is for identification purposes only and does not imply endorsement by the National Marine Fisheries Service, NOAA.
} 


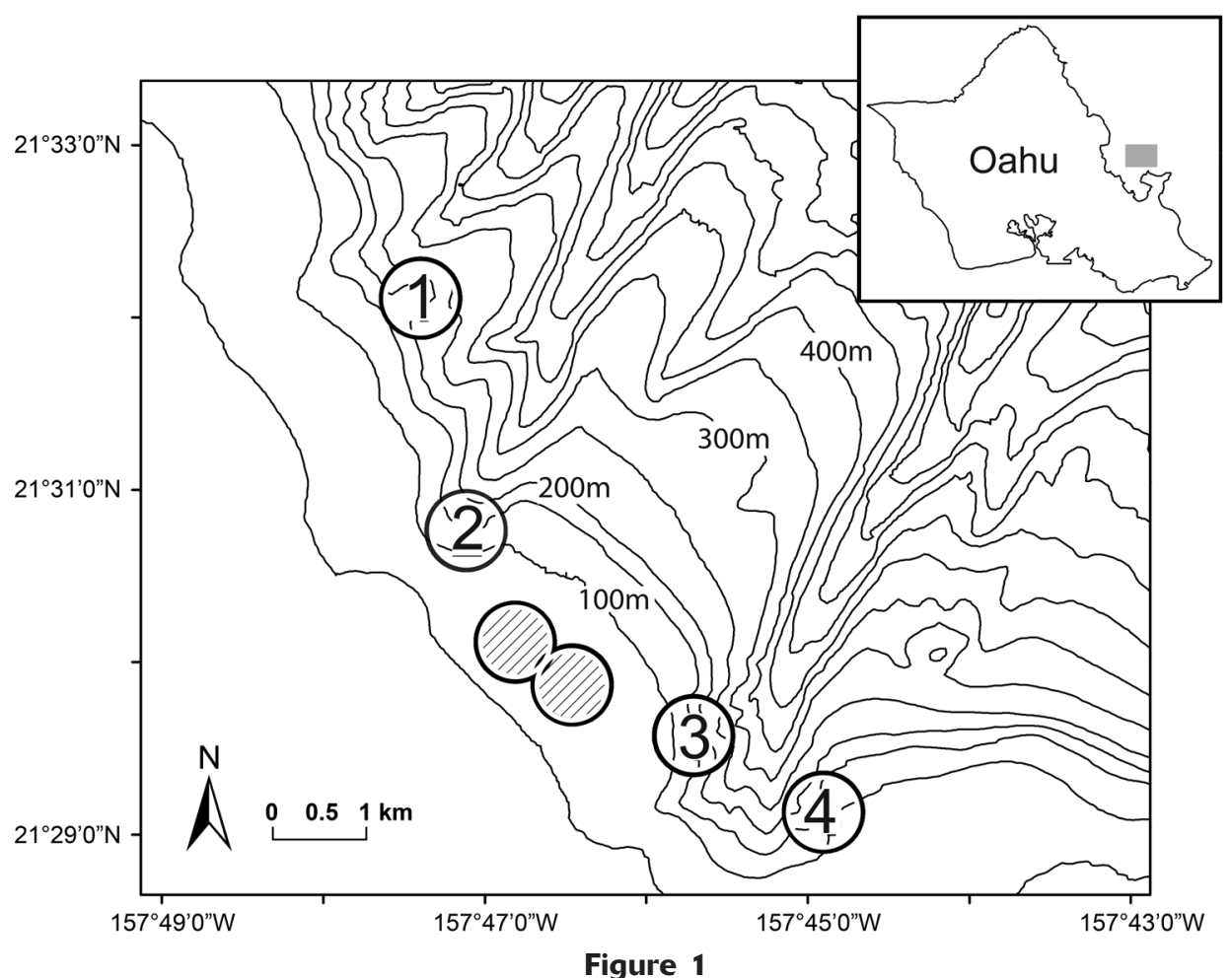

Map of the study area off windward Oahu, showing the deployment sites of 6 receivers with their $400-\mathrm{m}$ radiuses of detection. The gray rectangle in the inset map indicates the position of the study area off the island of Oahu. Two receivers, the locations of which are indicated by the circles filled with diagonal lines, monitored movements of tagged juvenile crimson jobfish (Pristipomoides filamentosus) in the snapper nursery on a terrace outside of Kaneohe Bay where tagged cultured and wild crimson jobfish were released in 2006 and 2007, respectively. Open circles indicate the sites (numbered 1-4) where additional receivers were deployed in 2007 to monitor the use by the tagged wild fish of rock ledge (sites 1 and 4) and soft bottom (sites 2 and 4) habitats on the slope adjacent to the nursery. Lines indicate depth contours in meters.

conut Island in Kaneohe Bay. Broodstock juveniles were originally captured from the Kaneohe nursery and raised through sexual maturity in floating pens. Spawned eggs were collected from the broodstock pens and transferred to tanks in a fish hatchery facility at HIMB. Larvae were raised in tanks for 4 months, then transferred to floating pens where rearing continued until they were 8 months of age and had grown to 20-24 cm FL, a considerably faster growth rate than those reported for wild fish and based on otolith analyses (DeMartini et al., 1994; Andrews et al., 2012). The acoustic tags were surgically implanted, and the fish were held in a floating pen for 4 days to verify that they continued to swim and feed actively.

Wild juveniles (17-30 cm FL) were collected from the Kaneohe nursery by hook and line, verified as crimson jobfish (Uchida and Uchiyama, 1986), implanted with acoustic tags, and observed in a floating holding pen for 10 days until ocean conditions permitted transport of fish to the nursery site for release. Two fish died, the first within an hour of surgery and the second that evening. All other fish schooled and fed normally during days of observation.

The tags were V9 transmitters (VEMCO; $69 \mathrm{kHz}$, 9 by $21 \mathrm{~mm}$ ), each of which had a unique code, was sterilized with alcohol, and inserted into the ventral abdominal cavity of a fish through a $1-\mathrm{cm}$ incision while that fish was anesthetized in a bath of tricaine methanesulfonate (Finquel MS-222, Argent Chemical Laboratories, Redmond, WA). Iodine and binding tissue adhesive were applied to the wound, and it was closed with a square knot suture made with a 2.0 surgical needle. To minimize handling, the lengths of both cultured and wild fish were measured in the water and the percentage of tag weight to body weight was estimated by using a published length-weight relationship for juvenile crimson jobfish $(n=125)$ collected from the study area (Moffitt and Parrish, 1996). In the sample of fish tagged, the tags never exceeded $4 \%$ of the body weight (Brown et al., 1999).

On the day of release, we used a receiver to confirm that the tag in each fish was functioning and transmit- 
ting a signal. At the Kaneohe nursery, the fish were split equally into 2 batches and released at the surface over each of the 2 receiver moorings. A snorkeler observed that all fish swam down (to a depth of $\sim 30 \mathrm{~m}$ ) and disappeared from sight within a minute. Tags had an expected life of 95 days and emitted a signal with a pseudorandom delay at an average of $100 \mathrm{~s}$. Cultured fish were released on 23 June 2006 and monitored for 58 days; wild fish were released on 10 July 2007 and monitored for 76 days.

\section{Data analysis}

We assumed a detection radius of $400 \mathrm{~m}$ for the receivers that was based on the results from the manufacturer's range calculator (Website) when we used the inputs of the tag power (151 db) and using the average windward Oahu wind speed (15-20 kt). Wind speed affects sea-surface conditions and introduces background noise that impacts the travel of transmitter signals underwater. Simultaneous detections were rare and only occurred between the 2 receivers deployed on the nursery site; they were the receivers closest to each other and monitored approximately half the area of the nursery habitat. The rest of the receivers allowed us to monitor habitat on the slope and were spaced far enough apart to avoid overlapping detections. It was necessary to discern signals from a tag on a resident, live fish from signals from a tag that was still transmitting but lost on the bottom for various reasons (e.g., tag expulsion or death of fish). For the purposes of this study, signals were assumed to be emitted from dead fish if 1) they had an inordinately high number of detections (e.g., >15,000) consistent with the detection of the continuous transmitting of a tag lost on the bottom for the full duration of the surveillance period and 2) they were detected by only 1 receiver.

Because prior tracking (Moffitt and Parrish, 1996) indicated that movement patterns of fish in the nursery differed between day and night, the detections of the fish in our study were binned in 6-h intervals for analysis (2400-0559, 0600-1159, 1200-1759, and 1800-2359). Initially, the density of tagged fish (and the risk of signal collisions) was high; therefore, we required 2 or more successive signals detected within 1 $\mathrm{h}$ to provide greater temporal resolution for the first 3 days. We defined a signal as "successive" if it was a repeat signal detected within 5 min of the previous signal-a time period adequate enough for 2 detections given the cycle of the tag's delay between transmissions. After 3 days, when most of the fish had departed, the risk of signal collisions that create false detections was reduced; therefore, multiple $(>2)$ isolated detections (spaced more than 5 min apart) were accepted as long as they fell within the 6-h time interval. Combining successive detections binned by time intervals increased confidence that the fish were actually present (94.5\% confidence intervals binned by hour, $97.9 \%$ by 6 h) and rendered insignificant the effect on our analysis of erroneous detections from signal collisions of multiple tags (see Pincock ${ }^{4}$ ).

We used the data from the 2 nursery receivers to look at patterns of time spent in the nursery, of influences of temperature, and of fish body length. Data recorded by the 4 slope receivers were used to examine patterns of habitat use by wild fish as they travelled away from the nursery. The sample size of fish was suitable for detecting large effect sizes at a power of 0.80 with an alpha of 0.10 (Cohen, 1988). All statistical analyses were performed in IBM SPSS, vers. 22 (IBM, Armonk, NY). Normalized data fitted to a negative exponential distribution showed how close the decline in fish detections was to a constant rate. In other comparisons, analysis of variance (ANOVA), correlation, and standard nonparametric tests (e.g., Mann-Whitney [MW] and Kruskal-Wallis [KW]) were used to analyze patterns in fish movements over time and in relation to body size and habitat (Siegel and Castellan, 1988).

\section{Results}

\section{Tag detections in the nursery}

Movements documented through tag detections indicated that 18 cultured fish and 28 wild fish were alive and suitable for inclusion in the analysis (Table 1). Seven other fish were excluded, including 2 wild fish that went undetected, 2 wild fish that were present only briefly (<10 signals), and 2 cultured and 1 wild fish whose tags emitted continuous signals recorded by 1 receiver (an indication that the tags were immobile and lying on the bottom because of tag expulsion or the death of a fish). Detections of tags lost on the bottom were unaffected by daily tidal changes in the temperature cycle, indicating that there was little effect from the thermocline on the reception of the receivers. Almost all $(97 \%)$ of the tagged fish (cultured and wild) used in the analysis moved back and forth between the 2 nursery receivers, indicating that the fish were active.

The signals of both cultured and wild fish declined exponentially to a low and variable level of presence by the end of the surveillance period in each year. Within 3 days of release, the portion of released cultured fish that were detected in the nursery area dropped to less than $20 \%$ in a pattern that closely fitted an inverse exponential curve (adjusted coefficient of multiple determination, $R^{2}=0.821$ ). In contrast, $75 \%$ of wild fish persisted in the nursery for 3 days, reducing the fit to the curve (adjusted $R^{2}=0.205$ ) and, therefore, indicating that the decline was not as continuous as the drop observed for cultured fish (Fig. 2).

\footnotetext{
${ }^{4}$ Pincock, D. G. 2012. False detections: what they are and how to remove them from detection data. Application note. AMIRIX Systems Inc. DOC-004691-03, 11 p. [Available at Website.]
} 


\section{Table 1}

Fish tag number, fish type, and fork length (FL) in centimeters of juvenile crimson jobfish (Pristipomoides filamentosus), as well as the number of days they were detected during this study off windward Oahu in 2006 and 2007, number of receivers in the nursery that detected them, and number of receivers on the adjacent slope that detected these fish. The right column lists the figure numbers in this article in which each fish is plotted. NA=not applicable.

\begin{tabular}{|c|c|c|c|c|c|c|}
\hline Fish tag & Fish type & $\mathrm{FL}(\mathrm{cm})$ & $\begin{array}{c}\text { Duration } \\
\text { (days) }\end{array}$ & $\begin{array}{l}\text { Number of } \\
\text { nursery } \\
\text { receivers }\end{array}$ & $\begin{array}{c}\text { Number of } \\
\text { slope } \\
\text { receivers }\end{array}$ & $\begin{array}{c}\text { Figure } \\
\text { number(s) }\end{array}$ \\
\hline 691 & Cultured & 23 & 1 & 2 & NA & 2 \\
\hline 692 & Cultured & 23 & 52 & 2 & NA & 2 \\
\hline 693 & Cultured & 23 & 2 & 2 & NA & 2 \\
\hline 695 & Cultured & 23 & 2 & 2 & NA & 2 \\
\hline 696 & Cultured & 24 & 1 & 2 & NA & 2 \\
\hline 697 & Cultured & 22 & 1 & 2 & NA & 2 \\
\hline 698 & Cultured & 20 & 1 & 2 & NA & 2 \\
\hline 699 & Cultured & 24 & 2 & 2 & NA & 2 \\
\hline 700 & Cultured & 21 & 1 & 1 & NA & 2 \\
\hline 701 & Cultured & 23 & 50 & 2 & NA & 2 \\
\hline 702 & Cultured & 23 & 1 & 2 & NA & 2 \\
\hline 703 & Cultured & 24 & 49 & 2 & NA & 2 \\
\hline 704 & Cultured & 24 & 1 & 2 & NA & 2 \\
\hline 705 & Cultured & 23 & 2 & 2 & NA & 2 \\
\hline 706 & Cultured & 24 & 2 & 2 & NA & 2 \\
\hline 708 & Cultured & 23 & 3 & 2 & NA & 2 \\
\hline 709 & Cultured & 22 & 53 & 2 & NA & 2 \\
\hline 710 & Cultured & 23 & 3 & 2 & NA & 2 \\
\hline 1830 & Wild & 27 & 48 & 2 & 2 & 2,3 \\
\hline 1831 & Wild & 30 & 75 & 2 & 2 & 2,3 \\
\hline 1832 & Wild & 22 & 4 & 2 & 1 & 2,3 \\
\hline 1833 & Wild & 22 & 28 & 2 & 2 & 2,3 \\
\hline 1834 & Wild & 22 & 29 & 2 & 1 & $2,3,5$ \\
\hline 1835 & Wild & 19 & 75 & 2 & 0 & $2,3,5$ \\
\hline 1838 & Wild & 30 & 4 & 2 & 1 & 2,3 \\
\hline 1839 & Wild & 18 & 49 & 2 & 1 & 2,3 \\
\hline 1840 & Wild & 19 & 61 & 2 & 2 & 2,3 \\
\hline 1841 & Wild & 30 & 9 & 2 & 1 & 2,3 \\
\hline 1842 & Wild & 23 & 75 & 1 & 1 & 2,3 \\
\hline 1843 & Wild & 18 & 9 & 2 & 1 & 2,3 \\
\hline 1844 & Wild & 22 & 44 & 2 & 0 & $2,3,5$ \\
\hline 1847 & Wild & 17 & 5 & 1 & 1 & 2,3 \\
\hline 1848 & Wild & 26 & 5 & 2 & 1 & 2,3 \\
\hline 1849 & Wild & 30 & 74 & 2 & 2 & 2,3 \\
\hline 1850 & Wild & 18 & 60 & 2 & 2 & $2,3,5$ \\
\hline 1856 & Wild & 30 & 10 & 2 & 2 & 2,3 \\
\hline 1857 & Wild & 28 & 9 & 2 & 3 & 2,3 \\
\hline 1858 & Wild & 19 & 5 & 1 & 3 & 2,3 \\
\hline 1859 & Wild & 20 & 65 & 2 & 1 & 2,3 \\
\hline 1860 & Wild & 23 & 20 & 2 & 1 & 2,3 \\
\hline 1862 & Wild & 20 & 9 & 2 & 0 & 2,3 \\
\hline 1863 & Wild & 18 & 4 & 2 & 1 & 2,3 \\
\hline 1864 & Wild & 23 & 24 & 2 & 1 & 2,3 \\
\hline 1866 & Wild & 30 & 17 & 2 & 3 & 2,3 \\
\hline 1867 & Wild & 20 & 12 & 0 & 1 & 2,3 \\
\hline 1869 & Wild & 23 & 2 & 2 & 0 & 2,3 \\
\hline
\end{tabular}




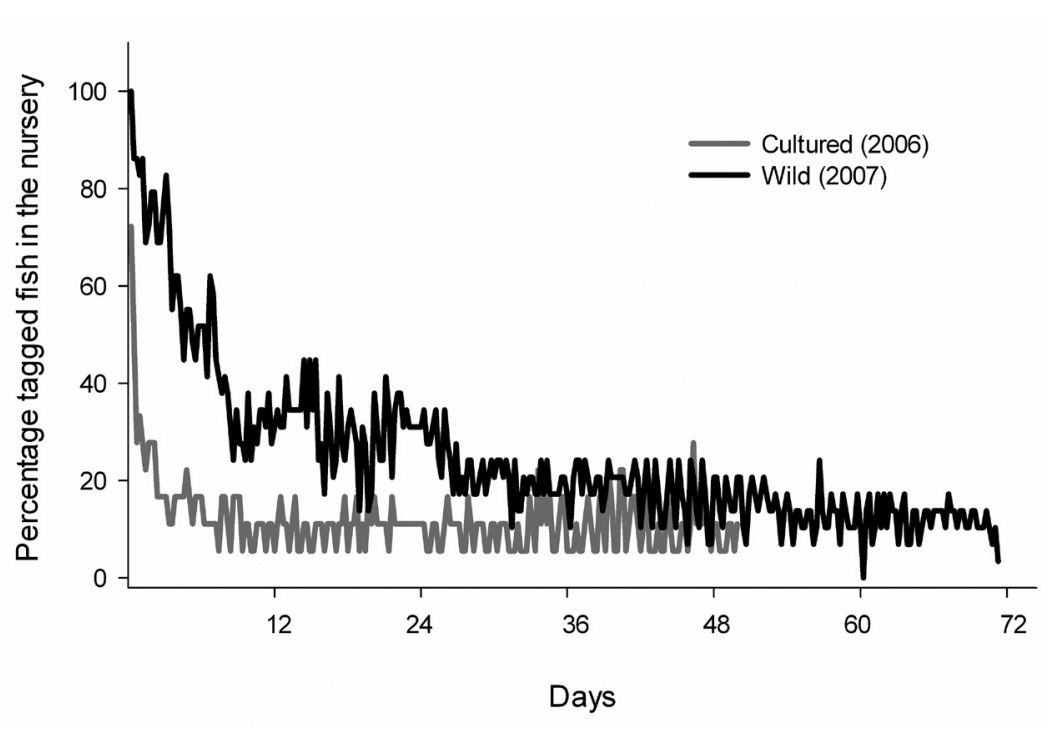

Figure 2

Percentage of cultured and wild juvenile crimson jobfish (Pristipomoides filamentosus) detected with acoustic telemetry over time after their release in the nursery offshore of Kaneohe Bay, windward Oahu, in 2006 and 2007, respectively, to observe their movements.

The tidally driven cycle of bottom temperature in the nursery is another variable that potentially could influence fish behavior. Prior work has shown that high tides pushed a cooler, bottom-associated lens of water $\left(\sim 2{ }^{\circ} \mathrm{C}\right.$ colder $)$ into the nursery (Moffitt and Parrish, 1996). Our data loggers on the bottom confirmed this tidal influx of cold water for both years with the temperature cycle ranging between $22.0^{\circ} \mathrm{C}$ and $25.5^{\circ} \mathrm{C}$ (Fig. 4). This prominent environmental feature is present interannually, but the cyclical change in temperature did not appear to control the behavior of the fish in our study. Tag detections indicate that 4 of the wild crimson jobfish (18-22 cm FL) stayed at the nursery for multiple weeks, and, during that time, they showed no behavioral change attributable to the temperature cycle (Fig. $5)$. One of those wild fish (tag 1835) moved from the range of one receiver on the terrace to the other receiver and then adopted a pattern of being present during the day and absent at

The mean fork lengths of the 2 groups were similar (cultured: $22.3 \mathrm{~cm}$ [SD 1.0]; wild: $23.1 \mathrm{~cm}$ [SD 4.5]), but the range was greater for wild fish. However, even in an analysis where the sample of wild fish was limited in relation to fish in the narrower size range of cultured fish (20-24 cm FL), the wild fish still persisted in the nursery significantly longer than cultured fish (MW: $Z=-2.6, P<0.01)$. Comparison of the body lengths of all wild fish according to time spent in the nursery showed that bigger fish left sooner (coefficient of correlation, $r=-0.39, n=28, P<0.05)$.

\section{Light and temperature}

The wild fish lingered in the nursery for 3 days after release, and documented movements indicate a bimodal pattern of higher numbers of the wild fish in the nursery during the day than during the night, indicating that the fish were diurnally active (Fig. 3 ). The inflection point in the pattern of data for high and low fish numbers was most obvious around dawn and dusk and the larger daytime numbers were statistically significant (ANOVA: $F=23.7, P<0.001$ ). In the evening, when detections in the nursery were lower, there was no corresponding increase in the number of fish detected at the receivers on the slope adjacent to the nursery $(t=-0.57, P=0.572)$ night. Movements of the other 3 fish (tags 1834, 1850, and 1844) showed that they remained continuously within the range of detection for large portions of the period regardless of changes in temperature.

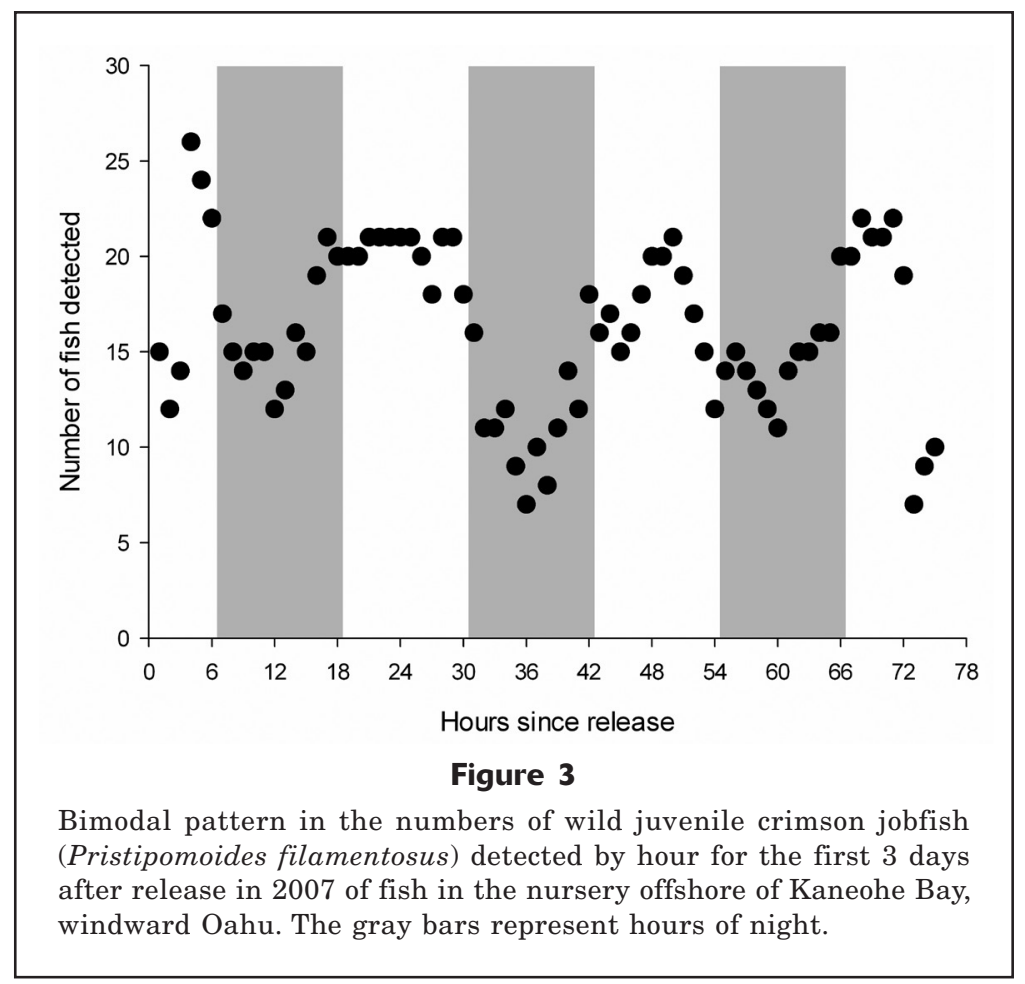




\section{Wild fish movements on the slope}

One or more of the 4 slope receivers was visited by $85 \%$ of the wild fish. Some fish passed them briefly, as they emigrated away from the nursery into deeper waters, and others chose to linger on the slope for a while before moving deeper. All the receivers were visited, but more than half the tagged fish visited the slope receiver closest to the nursery (located at site 2 north of the nursery; Fig. 1) (Table 2 ). There was no significant difference in the number of fish visiting soft bottom versus rock ledge habitats (MW: $Z=-1.3$, $P=0.21$ ). The number of days the fish lingered at the slope sites varied widely because of their habitat type and distance from the nursery; however, a mixed-effects model showed that the longest stays were at the sites with rock ledges (sites 1 and 3; Fig. 1) $(F=4.99, P=0.012)$. The range of fish lengths (18-30 cm FL) did not significantly differ between substrate types (MW: $Z=-0.172, P=0.88)$. Temperatures at the 4 slope receivers were on average $2^{\circ} \mathrm{C}$ cooler (Table 2) than the temperatures at the 2 receivers in the nursery. Only at slope site 3 , located to the south of the nursery close to the head of a deep canyon, were average temperatures nearly $1^{\circ} \mathrm{C}$ cooler than the average temperatures at the locations of other slope receivers (KW: $\chi 2=633$, $P<0.001)$. The receiver at site 3 recorded 3 of the 4

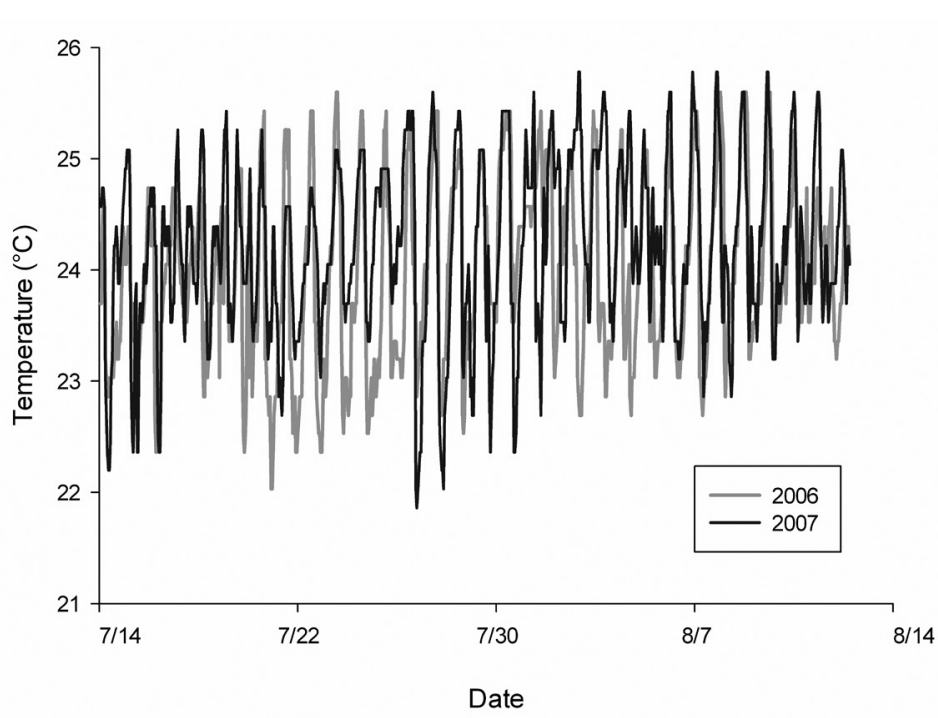

Figure 4

Bottom temperatures in degrees Celsius recorded over the same period at the sites off windward Oahu where crimson jobfish (Pristipomoides filamentosus) were released in 2006 (cultured fish) and in 2007 (wild fish), showing similar tidally driven fluctuations between $22.0^{\circ} \mathrm{C}$ and $25.5^{\circ} \mathrm{C}$ in both years.

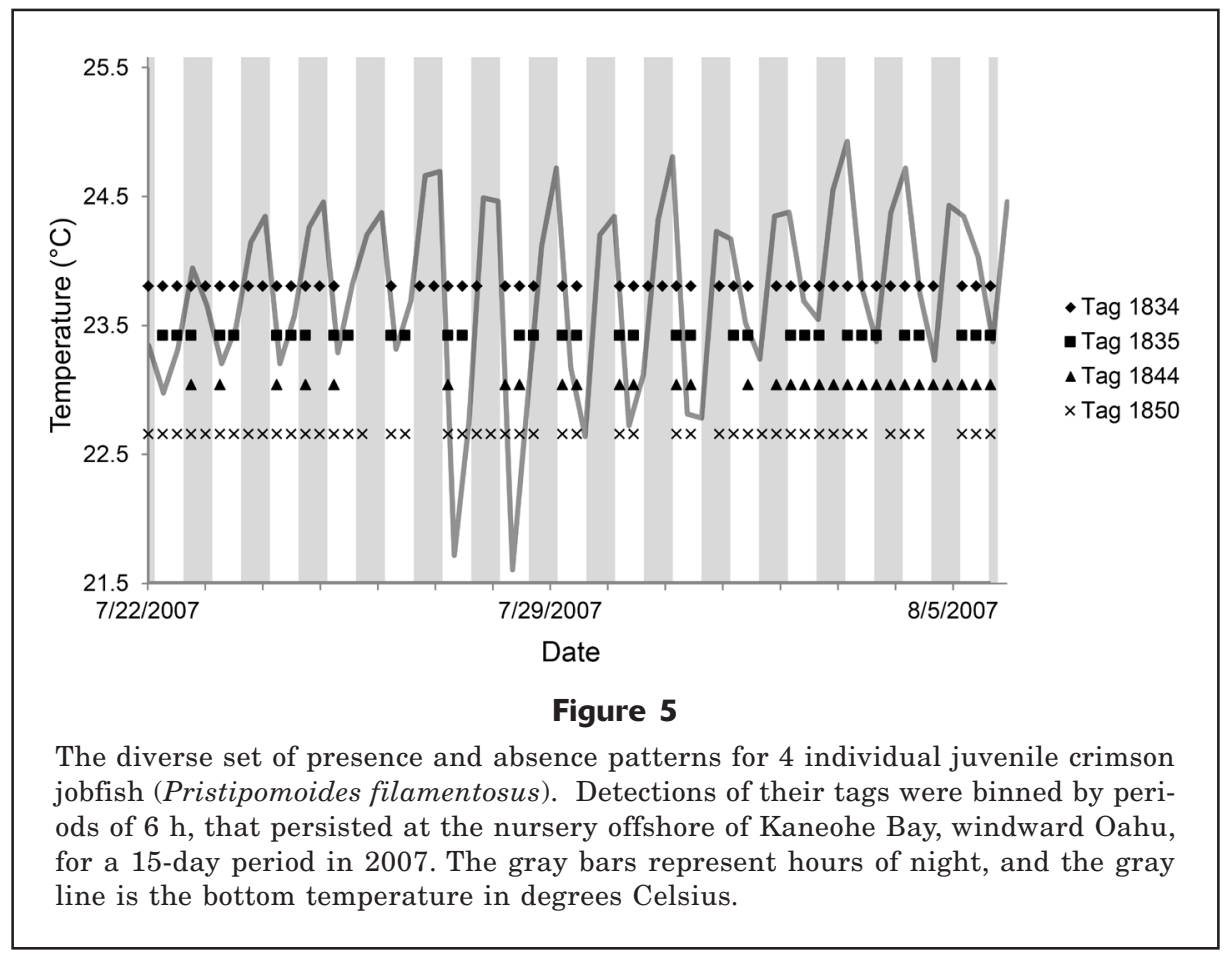




\section{Discussion}

\section{Time in the nursery}

It is unknown why the signals of cultured fish released in the first year of this study disappeared faster than wild fish in the second year. This release is the first one of a deepwater fish species raised in captivity. There are many potential factors, such as depth, light levels, and temperature, that likely influenced the behavior of the released cultured fish. Cultured fish reared in the warm surface water of a bay cage had none of the familiarity with the nursery habitat that the wild fish had. The released wild fish lingered because they knew the site, they had not yet matured enough to emigrate, or there were significant environmental differences between years that influenced fish behavior.

Environmental effects, including freshwater discharge, have been reported to influence the behavior of tagged marine species in coastal estuaries during their early life history (Manderson et al., 2014). The Kaneohe nursery differs from nurseries in estuarine habitats, because it is located deep, at the edge of an oceanic slope, where the substrate, temperature (Moffitt and Parrish, 1996), and nutrients (Parrish et al., 1997) have been found to be consistent between years in prior studies. The temperature records from both tagging years in this study were similar, and there is no clear association between temperature and behavior of the crimson jobfish. The original plan was to conduct a simultaneous release of cultured and wild fish in 2007 to compare their behavior, but the funding for the culture program was unexpectedly cut. Future studies are needed to distinguish whether interannual environmental effects are indeed a concern or whether the observed fish behavior is due to the inability (or a lack of need) for cultured juvenile fish to integrate into an assemblage of wild juveniles.

\section{Potential tagging effects}

Surgical implantation of acoustic tags in small fish has the potential to add significant weight and affect the fish's buoyancy and behavior. Prior studies (McCleave and Stred, 1975; Adams et al., 1998) recommended that tags should be no more than $2 \%$ of fish body weight. The V9 tags exceeded this percentage for 8 of our fish; 1 tag in 1 fish accounted for as high as $3.3 \%$ of estimated body weight. However, all the fish fell well within the percentage of tag weight identified by Brown et al. (1999), who showed success with the use of tags that were $6-12 \%$ of body mass of juvenile salmon (smolt). Our observations of fish actively swimming in the holding pen for days before release and documented movement between receivers after release indicate that there was little behavioral effect from the size of the tags used.

Having endured the stress of tagging, release, and descent through the water column, most of the released fish successfully reached the bottom where they were repeatedly detected for a day or more by the nursery receivers. A single $20-\mathrm{cm}$ fish (tag 1867) was not detected by either of the nursery receivers after it was released, but it appeared 9 days later at site 3 on the adjacent slope (Fig 1). It stayed there for 2 days before disappearing from the study. The disappearance of tag signals is either the result of the fish emigrating outside the receiver surveillance area or of it being consumed by a predator that leaves the area. The featureless mud bottom of the nursery supports few other fish (DeMartini et al., 1996) that would be resident predators of the crimson jobfish; therefore, predation loss was likely from larger, transient fishes that passed through the nursery. Loss of tagged fish to predation is expected, although we have no way to evaluate the degree of this impact.

\section{Movement of wild fish}

There have been few studies of tagged deepwater snappers and most of them have been of adult fish. The most recent work (Weng, 2013) looked at movements of tagged adult eteline red snappers and found that ruby snapper (Etelis carbunculus) showed more fidelity to the area of their release than did tagged flame snapper (Etelis coruscans). A separate study of 18 tagged adult crimson jobfish (40-60 cm FL) showed that $75 \%$ of fish remained in the monitored release area (Ziemann and Kelley $^{5}$ ). Because those mature fish had already immigrated to their adult habitat, we might expect greater fidelity for them than for the juvenile fish in our study. In contrast, we examined the temporary use of nursery habitat by juveniles before they moved to the next stage in their life history.

The time spent in the nursery varied from a few days to multiple weeks. For many of the fish tagged in our study, diurnal movements were detected in and out of the range of receivers in the nursery. The study on tagged adult crimson jobfish found that they aggregated during the day and ranged over a wider area at night (Ziemann and Kelley ${ }^{5}$. The movements of the juveniles in our study were much more limited. The receivers deployed on the slope adjacent to the nursery did not detect a greater number of juvenile crimson jobfish during evening hours than during daytime hours; an increase would be expected if the fish were engaged in wide-ranging movements. It is possible that the juveniles could have moved inshore to shallower depths; however, data from a previous study that conducted boat-based tracking of 2 juveniles indicated that the fish would move deeper (Moffitt and Parrish, 1996). The individual tracks of both fish showed crepuscular movements, the fish stayed in shallower wa-

\footnotetext{
${ }^{5}$ Ziemann, D., and C. Kelley. 2004. Detection and documentation of bottomfish spillover from the Kaho'olawe Island Reserve. Final report submitted to the Kaho'olawe Island Reserve Commission for Study I. [Available from Kaho'olawe Island Reserve Commission, 811 Kolo St., Ste. 201, Wailuku, HI 96793.]
} 


\section{Table 2}

The identification number and substrate type of the 4 sites on the windward Oahu slope where receivers were deployed in 2007. Also shown is the distance in kilometers of each receiver from the nursery, number of tagged juvenile crimson jobfish (Pristipomoides filamentosus) that were detected, mean number of days when those fish were present at each site, and mean bottom temperature at each site. For "Days present" the mean, standard deviation (SD), and range are given for each site. There were 2 substrate types: rock ledge and soft bottom.

\begin{tabular}{|c|c|c|c|c|c|c|}
\hline \multirow[b]{2}{*}{ Receiver } & \multirow[b]{2}{*}{ Substrate } & \multirow[b]{2}{*}{ Nursery $(\mathrm{km})$} & \multirow[b]{2}{*}{ No. fish } & \multicolumn{2}{|c|}{ Days present } & \multirow{2}{*}{$\frac{\text { Temp. }\left({ }^{\circ} \mathrm{C}\right)}{\text { Mean }(\mathrm{SD})}$} \\
\hline & & & & Mean (SD) & Range & \\
\hline 1 & Rock & 4.0 & 5 & $6.0(9.9)$ & $0.25-23.5$ & $21.8(1.0)$ \\
\hline 2 & Soft & 1.5 & 17 & $1.5(2.0)$ & $0.25-8.3$ & $21.8(1.0)$ \\
\hline 3 & Rock & 1.8 & 8 & $17.8(25.2)$ & $0.25-61.0$ & $21.0(1.0)$ \\
\hline 4 & Soft & 3.3 & 8 & $0.6(0.4)$ & $0.25-2.0$ & $21.8(1.0)$ \\
\hline
\end{tabular}

ter during the day and in deeper water at night, shifting between adjacent areas $(<300 \mathrm{~m}$ separation) that differed slightly in depth $(\sim 10 \mathrm{~m})$. For both tracks, the area of daytime activity was twice the size of the area of activity at night.

This commuting behavior could explain the bimodal pattern seen for the tagged fish in our study before they left the nursery. If these fish also shifted deeper at night, some of them would be out of detection range until morning when they returned to the shallower portion of their home range and were more active. Looking at the patterns in the movements of the 4 wild fish that persisted in the nursery for multiple weeks, 2 fish (tags 1834 and 1850) appeared to have both their areas of activity during day and night mostly inside the detection area of the receivers in the nursery (Fig. 5 ). In contrast, the pattern of a third fish (tag 1835) indicates that the area of activity during the day was within the detection range of the receiver and the area of nighttime activity was outside that range. Some drift in the home range of individual fish can occur, as was observed for the fourth wild fish (tag 1844) that stayed at the nursery for multiple weeks, but the extent to which the size or location of home ranges are subject to change over time is unknown.

As the wild fish departed the nursery and ranged farther out on the slope, they used both soft bottom and rock ledge habitats before emigrating away. Although the size of the fish at the sites on the slope did not statistically differ by habitat type of sites, a few of the larger fish (mean: $25.5 \mathrm{~cm} \mathrm{FL}$ [SD 5.4]) clearly persisted for more than a month at sites with rock ledges. Crimson jobfish at this size are at the lower end of the size range of subadults documented to aggregate around relief features $\left(\right.$ Okamoto $\left.^{1}\right)$. Presumably, this shift in habitat use occurs because the fish grow to a size where they need to change their diet or foraging strategy. Studies of stomach contents of crimson jobfish have shown a transition from a juvenile diet of mostly benthic invertebrates (DeMartini et al., 1996) to an adult diet of mostly large plankton, including jellies and salps (Haight et al., 1993b). Maturing and adult fish use high-relief habitat more than juveniles do-they exploit the increased water flow around relief features to improve their level of success in encountering and feeding on drifting plankton over their level of success at low-relief habitats. Future tagging work in the Kaneohe nursery should include receivers deployed in nearby locations with adult crimson jobfish assemblages to see if some of the emigrating juveniles make a direct transition to adult habitat.

\section{Considerations for stock enhancement}

Although we have no explanation for the behavioral difference seen between the 2 batches of tagged fish, the patterns observed for wild and cultured fish are similar to findings from other marine fish studies. Simultaneous releases of tagged cultured and wild individuals generally have shown that cultured fish tend to move away sooner and farther than wild fish (D'Anna et al., 2004; Yokota et al., 2007; Fairchild et al., 2009; Lino et al., 2009). Future studies with releases of tagged juvenile crimson jobfish might include a staged release process (Fairchild et al., 2010) that would give fish time to acclimate to the nursery and, therefore, make them more likely to use the habitat like wild fish. However, if cultured fish were to continue to leave the nursery directly, and there were no means to verify their survivorship after they have left, the use of larger fish $(\geq 30 \mathrm{~cm} F L)$ that are old enough to skip the nursery stage and join subadults or adults should be considered for enhancement efforts. Stock enhancement studies on shallower Hawaiian species have shown that the size of release is an important variable in the success of stocking efforts (Leber, 1995; Leber et al., 1998; Leber et al., 2005). Finally, it is possible that being reared, or even just being held for a time in captivity and fed, can accelerate the ontogentic shift from the nursery stage to subadult phase in the life history of the crimson job- 
fish. For example, the type or amount of food is likely to be better calorically in captivity than in the wild (Alasalvar et al., 2002; Gregorakis et al., 2002; Handeland et al., 2003; Periago et al., 2005; Benetti et al., 2010), and it could accelerate the development of the reserves a fish needs to graduate to the next habitat during its life history.

Within 3 days of release, the majority of tagged fish in both years departed from the nursery, although cultured fish exited at twice the rate of wild fish. There were no obvious environmental differences seen between years that could explain the different behavior patterns. For the batch of wild fish, higher numbers were detected during daylight hours than at night, and the movement of fish that stayed in the nursery for multiple weeks did not correspond with tidally driven changes in bottom temperature. Larger juveniles ( $>25$ $\mathrm{cm}$ FL) emigrated away from the nursery earlier; twothirds of these juveniles traveled across soft bottom habitats (mean: 1.2 days [SD 1.69]) and the rest lingered in areas with rock ledges (mean: 13.3 days [SD 20.9]). Our research indicates that juvenile crimson jobfish cultured in the laboratory or pulled from the wild will quickly emigrate even if released in a viable nursery habitat. This behavior prompts a number of ontogenetic, behavioral, and survivorship questions for future study that are particularly relevant for aquaculture as a means to enhance the stock of deep-slope fish species.

\section{Acknowledgments}

This research was supported by a grant from the State of Hawaii Fishery Disaster Relief Program (grant \# 657788). Wild fish were obtained under a State of Hawaii Scientific Collection Permit with the help of $\mathrm{R}$. Sixberry. Surgical procedures were in accordance with guidelines of the University of Hawaii Institutional Animal Care \& Use Committee (6 August 2006). Helpful comments on the manuscript were provided by D. Kobayashi, E. DeMartini, and a number of anonymous reviewers.

\section{Literature cited}

Adams, N. S., D. W. Rondorf, S. D. Evans, and J. E. Kelly. 1998. Effects of surgically and gastrically implanted radio transmitters on growth and feeding behavior of juvenile Chinook salmon. Trans. Am. Fish. Soc. 127:128-136. Article

Alasalvar, C., K. D. A. Taylor, E. Zubcov, F. Shahidi, and M. Alexis.

2002. Differentiation of cultured and wild sea bass (Dicentrarchus labrax): total lipid content, fatty acid and trace mineral composition. Food Chem. 79:145-150. Article

Andrews A. H., E. E. DeMartini, J. Brodziak, R. S. Nichols, and R. L. Humphreys.

2012. A long-lived life history for a tropical, deepwater snapper (Pristipomoides filamentosus): bomb radiocar- bon and lead-radium dating as extensions of daily increment analyses in otoliths. Can. J. Fish. Aquat. Sci. 69:1850-1869. Article

Bell, J. D., K. M. Leber, H. L. Blankenship, N. R. Loneragen, and R. Masuda.

2008. A new era for restocking, stock enhancement and sea ranching of coastal fisheries resources. Rev. Fish. Sci. 16:1-9. Article

Benetti, D. D., B. O'Hanlon, J. A. Rivera, A. W. Welch, C. Maxey, and M. R. Orhun.

2010. Growth rates of cobia (Rachycentron canadum) cultured in open ocean submerged cages in the Caribbean. Aquaculture 302:195-201. Article

Brodziak, J., D. Courtney, L Wagatsuma, J. O’Malley, H.-H. Lee, W. Walsh, A. Andrews, R. Humphreys, and G. DiNardo. 2011. Stock assessment of the main Hawaiian Islands Deep7 bottomfish complex through 2010. NOAA Tech. Memo., NOAA-TM-NMFS-PIFSC-29, 176 p.

Brown, R. S., S. J. Cooke, W. G. Anderson, and R. S. McKinley. 1999. Evidence to challenge the " $2 \%$ rule" for biotelemetry. N. Am. J. Fish. Manage. 19:867-871. Article

Cohen, J.

1988. Statistical power analysis for the behavioral sciences $2^{\text {nd }}$ ed., 567 p. Lawrence Erlbaum Associates, Hillsdale, NJ.

D’Anna G., V. M. Giacalone, F. Badalamenti, C. Pipitone.

2004. Releasing of hatchery-reared juveniles of the white seabream Diplodus sargus (L., 1758) in the Gulf of Castellammare artificial reef area (NW Sicily). Aquaculture 233:251-268. Article

DeMartini, E. E., K. C. Landgraf, and S. Ralston.

1994. A recharacterization of the age-length and growth relationships of Hawaiian snapper, Pristipomoides filamentosus. NOAA Tech. Memo. NOAA-TM-NMFS-SWFSC-199, $14 \mathrm{p}$.

DeMartini, E. E., F. A. Parrish, and D. M. Ellis.

1996. Barotrauma-associated regurgitation of food: implications for diet studies of Hawaiian pink snapper Pristipomoides filamentosus (family Lutjanidae). Fish. Bull. 94:250-256.

Fairchild E. A., N. Rennels, and H. Howell.

2009. Using telemetry to monitor movements and habitat use of cultured and wild juvenile winter flounder in a shallow estuary. In Tagging and tracking of marine animals with electronic devices (J. L. Nielsen, H. Arrizabalaga, N. Fragoso, A. Hobday, M. Lutcavage, and J. Sibert, eds.), Rev.: Methods Technol. Fish Biol. Fish. 9:5-22. Article

Fairchild E. A., J. A. Sulikowski, N. Rennels, W. H. Howell, and P. C. W. Tsang.

2010. Effects of moving acclimation cages before release of cultured fish: alternate release strategies for a juvenile winter flounder Pseudopleuronectes americanus stock enhancement effort. Aquacult. Res. 41:602-606. Article

Friedlander, A. M., and D. A. Ziemann.

2003. Impact of hatchery releases on the recreational fishery for Pacific threadfin (Polydactylus sexfilis) in Hawaii. Fish. Bull. 101:32-43.

Gregorakis, K., M. N. Alexis, K. D. A. Taylor, and M. Hole.

2002. Comparison of wild and cultured gilthead sea bream (Sparus aurata); composition, appearance and seasonal variations. Int. J. Food Sci. Technol. 37:477-484. Article

Haight, W. R., D. R. Kobayashi, and K. E. Kawamoto.

1993a. Biology and management of deepwater snappers of the Hawaiian Archipelago. Mar. Fish. Rev. 55(2):17-24. 
Haight, W. R., J. D. Parrish, and T. A. Hayes. 1993b. Feeding ecology of deepwater lutjanid snappers at Penguin Bank, Hawaii. Trans. Am. Fish. Soc. 122:328-347. Article

Handeland, S. O., Björnsson, A. M. Arnesen, and S. O. Stefansson.

2003. Seawater adaptation and growth of post-smolt Atlantic salmon (Salmo salar) of wild and farmed strains. Aquaculture 220:367-384. Article

Leber, K. M.

1995. Significance of fish size-at-release on enhancement of striped mullet fisheries in Hawaii. J. World Aquacult. Soc. 26:143-153. Article

Leber, K. M., and S. M. Arce.

1996. Stock enhancement in a commercial mullet, Mugil cephalus L., fishery in Hawaii. Fish. Manage. Ecol. 3:261-278. Article

Leber, K. M., N. P. Brennan, and S. M. Arce.

1998. Recruitment patterns of cultured juvenile Pacific threadfin. Polydactylus sexfilis (Polynemidae), released along sandy marine shores in Hawaii. Bull. Mar. Sci. 62:389-408.

Leber, K. M., R. N. Cantrell, and P. S. Leung.

2005. Optimizing cost-effectiveness of size at release in stock enhancement programs. N. Am. J. Fish. Manage. 25:1596-1608. Article

Leis, J. M.

1987. Review of the life history of tropical groupers (Serranidae) and snappers (Lutjanidae). In Tropical snappers and groupers: biology and fisheries management (J. J. Polovina and S. Ralston, eds.), p. 189-237. Westview Press Inc., Boulder, CO.

Leis, J. M., and K. Lee.

1994. Larval development in the lutjanid subfamily Etelinae (Pisces): the genera Aphareus, Aprion, Etelis and Pristipomoides. Bull. Mar. Sci. 55:46-125.

Lino, P. G., L. Bentes, D. Abecasis, M. Neves dos Santos, and K. Erzini.

2009. Comparative behavior of wild and hatchery reared white sea bream (Diplodus sargus) released on artificial reefs off the Algarve (southern Portugal). In Tagging and tracking of marine animals with electronic devices (J. L. Nielsen, H. Arrizabalaga, N. Fragoso, A. Hobday, M. Lutcavage, and J. Sibert, eds.), Rev: Methods Technol. Fish Biol. Fish. 9:23-34. Article

Manderson, J. P., L. L. Stehlik, J. Pessutti, J. Rosendale, and

B. Phelan.

2014. Residence time and duration for predators in a small mid-Atlantic estuary. Fish. Bull. 112:144-158. Article
McCleave, J. D., and K. A. Stred.

1975. Effect of dummy telemetry transmitters on stamina of Atlantic salmon (Salmo salar) smolts. J. Fish. Res. Board Can. 32:559-563. Article

Moffitt, R. B., and F. A. Parrish.

1996. Habitat and life history of juvenile Hawaiian pink snapper, Pristipomoides filamentosus. Pac. Sci. 50:371-381.

Parrish, F. A.

1989. Identification of habitat of juvenile snappers in Hawaii. Fish. Bull. 87:1001-1005.

Parrish, F. A., E. E. DeMartini, and D. M. Ellis.

1997. Nursery habitat in relation to production of juvenile pink snapper, Pristipomoides filamentosus, in the Hawaiian Archipelago. Fish. Bull. 95:137-148.

Periago, Ma. J., Ma. D. Ayala, O. López-Albors, I. Abdel, C. Martínez, A. García-Alcázar, G. Ros, and F. Gil.

2005. Muscle cellularity and flesh quality of wild and farmed sea bass, Dicentrarchus labrax L. Aquaculture 249:175-188. Article

Schumacher, B. D.

2011. Habitat use and trophic ecology of the introduced snapper Lutjanus kasmira and native goatfishes in Hawaii. Ph.D. diss., 238 p. Univ. Hawaii, Honolulu, HI.

Siderius M., M. B. Porter, P. Hursky, V. McDonald, and Kauai Ex Group.

2007. Effects of ocean thermocline variability on noncoherent underwater acoustic communications. J. Acoust. Soc. Am. 121:1895-1908. Article

Siegel, S., and N. J. Castellan Jr.

1988. Nonparametric statistics for the behavioral sciences, 2nd ed., 399 p. McGraw-Hill, New York.

Uchida, R. N., and J. H. Uchiyama.

1996. Fishery atlas of the Northwestern Hawaiian Islands. NOAA Tech. Rep. NMFS 38, 142 p.

Weng, K. C.

2013. A pilot study of deepwater fish movement with respect to marine reserves. Anim. Biotelem. 1:17. Article

Yokota T., R. Masuda, N. Arai, H. Mitamura, Y. Mitsunaga, H.

Takeuchi, and T. Tsuzaki.

2007. Hatchery-reared fish have less consistent behavioral pattern compared to wild individuals, exemplified by red tilefish studied using video observation and acoustic telemetry tracking. Hydrobiologia 582:109-120. Article

Zeller, D., M. Darcy, S. Booth, M. K. Lowe, and S. Martell. 2008. What about recreational catch? Potential impact on stock assessment for Hawaii's bottomfish fisheries. Fish. Res. 91:88-97. Article 